\title{
Keratin, Type I Cytoskeletal 16
}

National Cancer Institute

\section{Source}

National Cancer Institute. Keratin, Type I Cytoskeletal 16. NCI Thesaurus. Code C118930.

Keratin, type I cytoskeletal 16 (473 aa, $\sim 51 \mathrm{kDa}$ ) is encoded by the human KRT 16 gene.

This protein plays a role in the maturation of the epidermis, hair follicles, and some

mucosal surfaces. 